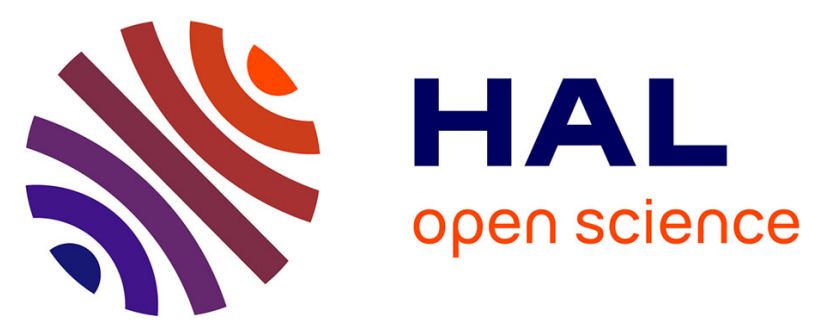

\title{
Reducing the environmental impact of poultry breeding by genetic selection
}

\author{
Hugues H. de Verdal, Sandrine Mignon-Grasteau, Denis Bastianelli, Nathalie \\ Meme, Elisabeth Le Bihan-Duval, Agnès Narcy
}

\section{- To cite this version:}

Hugues H. de Verdal, Sandrine Mignon-Grasteau, Denis Bastianelli, Nathalie Meme, Elisabeth Le Bihan-Duval, et al.. Reducing the environmental impact of poultry breeding by genetic selection. Journal of Animal Science, 2013, 91 (2), pp.613-622. 10.2527/jas.2012-5572 . hal-02650530

\section{HAL Id: hal-02650530 \\ https://hal.inrae.fr/hal-02650530}

Submitted on 29 May 2020

HAL is a multi-disciplinary open access archive for the deposit and dissemination of scientific research documents, whether they are published or not. The documents may come from teaching and research institutions in France or abroad, or from public or private research centers.
L'archive ouverte pluridisciplinaire HAL, est destinée au dépôt et à la diffusion de documents scientifiques de niveau recherche, publiés ou non, émanant des établissements d'enseignement et de recherche français ou étrangers, des laboratoires publics ou privés.

\section{(ㅇ)(1) $\$$}

Distributed under a Creative Commons Attribution - NonCommercial - NoDerivatives| 4.0 


\section{JOURNAL OF ANIMAL SCIENCE}

The Premier Journal and Leading Source of New Knowledge and Perspective in Animal Science

Reducing the environmental impact of poultry breeding by genetic selection H. de Verdal, S. Mignon-Grasteau, D. Bastianelli, N. Même, E. Le Bihan-Duval and A. Narcy

J ANIM SCI 2013, 91:613-622.

doi: 10.2527/jas.2012-5572 originally published online December 12, 2012

The online version of this article, along with updated information and services, is located on the World Wide Web at:

http://www.journalofanimalscience.org/content/91/2/613 


\title{
Reducing the environmental impact of poultry breeding by genetic selection ${ }^{1}$
}

\author{
H. de Verdal,* S. Mignon-Grasteau, $\dagger$ D. Bastianelli, $\$$ N. Même, $\dagger$ E. Le Bihan-Duval, $\dagger$ and A. Narcy $\dagger^{2}$ \\ *CIRAD, UMR 110 INTREPID, 34398 Montpellier Cedex 5, France; †INRA, UR83 Recherches \\ Avicoles, F-37380 Nouzilly, France; and \$CIRAD, UMR SELMET, 34398 Montpellier Cedex 5, France
}

ABSTRACT: Improving the sustainability of poultry
production involves limiting its environmental impact and
maintaining effectiveness. It has recently been shown that
genetic selection on the ability of chickens to digest wheat
at $23 \mathrm{~d}$ of age can decrease chicken excretion without
decreasing BW at this age. The aim of this study was to
check whether selection on digestibility modified excretion
and growth performance over the whole production
cycle. The 2 divergent lines selected for high (D+) and
low (D-) apparent metabolizable energy corrected for $0 \mathrm{~N}$
balance (AMEn) values were compared with a reference
line used at the beginning of the selection experiment
(RL) to evaluate the potential excretion improvement
that could be expected with such selection. These 3 lines
were therefore compared for growth and excretion (raw
and relative to feed intake, fresh and dry excreta weights,
and moisture content of excreta) from 4 to 53 d. Between
4 and $7 \mathrm{~d}$, 17 and $21 \mathrm{~d}$, and 49 and $53 \mathrm{~d}$, AMEn and $\mathrm{N}$
and P excretion rates were also compared between the
3 lines. Furthermore, body composition (breast meat
and abdominal fat yields), bone breaking strength, and
meat quality traits (lightness, redness, yellowness, and

ultimate $\mathrm{pH}$ ) were compared between lines at $53 \mathrm{~d}$. Over the whole rearing period, $\mathrm{D}+$ birds excreted significantly less fresh and dry excreta ( -56 and $-61 \%)$ than D- and RL birds ( -6 and $-26 \%)$. Similarly, $N$ and $P$ excretion rates of $\mathrm{D}+$ birds were $13 \%$ to $30 \%$ less than those of D- birds and $12 \%$ to $19 \%$ less than RL birds, depending on age. These excretion differences may be related to the differential development of the gastrointestinal tract. Differences between lines were already present at $7 \mathrm{~d}$ for relative gizzard weight and the weight of the upper to the lower part of the gastrointestinal tract ratio. Anatomic differences were maximum at $23 \mathrm{~d}$ for all traits except for relative weight of the duodenum. At slaughter age, BW, breast and fat yields, and meat color did not differ between $\mathrm{D}+$ and RL birds, but D- birds were fatter than $\mathrm{D}+$ and $\mathrm{RL}$ birds. Finally, ultimate meat $\mathrm{pH}$ was $1 \%$ to $2 \%$ greater in RL birds than in the D+ and D- lines. In conclusion, this study showed that selection of chickens for AMEn is a possible way to reduce the environmental impact of production over the whole rearing period without a negative impact on growth, body composition, or meat quality.

Key words: environment, poultry, selection

(C) 2013 American Society of Animal Science. All rights reserved.

J. Anim. Sci. 2013.91:613-622 doi:10.2527/jas2012-5572

\section{INTRODUCTION}

Environmental issues are of crucial importance for the poultry industry. Spreading chicken manure on fields causes environmental problems when undertaken

\footnotetext{
${ }^{1}$ The authors thank the Animal Genetics Department of INRA for financial support. We thank the PEAT experimental unit (UE 1295 Pôle Expérimental Avicole de Tours, INRA, Nouzilly, France) and especially K. Gérard for bird management, L. Bonnal (CIRAD, Montpellier, France) for his help in the NIRS measurements of the excreta, and all those who helped with the data collection.

${ }^{2}$ Corresponding author: agnes.narcy@tours.inra.fr

Received June 15, 2012.

Accepted November 15, 2012.
}

in excess in regions with a very dense production (Nahm, 2007; Bolan et al., 2010; Mignon-Grasteau et al., 2010a). Reducing poultry excretion and controlling its composition (especially in terms of $\mathrm{N}$ and $\mathrm{P}$ content) and physicochemical properties are therefore of major importance. It has long been accepted that digestibility is not controlled by genetics (Pym, 1990). Nevertheless, it has recently been shown that $\mathbf{D}+$ birds (birds selected for high apparent ME corrected for $0 \mathrm{~N}$ retention; AMEn) excreted $48.4 \%$ and $36.7 \%$ less $\mathrm{N}$ and $\mathrm{P}$, respectively, than the D- birds (birds selected for low AMEn) without modifying BW (Mignon-Grasteau et al., 2010b; de Verdal et al., 2011b). These differences in excretion rates 
could be explained by differential development of the gastrointestinal tract (de Verdal et al., 2011b). However, studies on these 2 divergent lines were performed on 3 -wk-old chickens, which was the age at selection.

The aims of the present study were therefore to evaluate the impact of selection according to AMEn on excretion traits, especially $\mathrm{N}$ and $\mathrm{P}$ excretion, until birds reach a commercial BW and to estimate its indirect impact on growth, body composition, meat quality, and bone strength. The evolution of the gastrointestinal tract morphology with age was also studied to understand the mechanisms involved in differences between lines. The line used at the beginning of the selection experiment to create the $\mathrm{D}+$ and $\mathrm{D}$ - lines was also included in the comparison to evaluate the potential practical improvement that can be expected from selection on digestibility. It is of note that this reference line (RL) has been selected for commercial purposes after the beginning of the selection experiment and is not properly a control line.

\section{MATERIAL AND METHODS}

The experiment was conducted under the guidelines of the French Ministry of Agriculture for Animal Research.

\section{Birds and Housing}

The experiment was performed on 144 birds (males and females), 48 birds from each line originating either from the ninth generation of the divergent selection experiment ( 8 generations of selection and 1 generation of maintenance) selected for high and low AMEn values or from the reference pure line used at the beginning of the selection experiment to create the $\mathrm{D}+$ and $\mathrm{D}$ - lines and not selected according to AMEn in the meantime. The latter was therefore considered as a RL. At hatching, chicks were reared in cages of 4 or 5 birds. After $4 \mathrm{~d}$, chicks were randomly allocated to individual cages in 2 rearing rooms. At $21 \mathrm{~d}$, the remaining birds from each line were allocated to another rearing room, with cages appropriate to their BW. Environmental conditions were controlled for ventilation, lighting program ( $24 \mathrm{~h}$ light: $0 \mathrm{~h}$ dark from $\mathrm{d} 1$ to 6 and $18 \mathrm{~h}$ light: $6 \mathrm{~h}$ dark from $\mathrm{d} 7$ to 53 ), and temperature (from $33^{\circ} \mathrm{C}$ at $\mathrm{d} 1$ to $20^{\circ} \mathrm{C}$ at $\mathrm{d} 53$ ). Birds had free access to water and feed. Mortality was recorded daily. Birds were fed a starter and a grower wheat-based diet from hatching to $21 \mathrm{~d}$ and from 22 to $53 \mathrm{~d}$, respectively (Table 1).

\section{Recorded Traits}

Animals were weighed at 4, 7, 18, 21, 49, and $53 \mathrm{~d}$ (BWx, where $x$ is age). Parameters of the growth curve were estimated using Gompertz equation, according to Laird et al. (1965)

$$
\begin{aligned}
& \mathrm{BW} x=\mathrm{BW} 0 \times \exp \{[(\mathrm{iGR} / \mathrm{K}) \\
& \times \quad(1 \quad-\quad \exp (-\mathrm{K} x)]\}, \quad[1]
\end{aligned}
$$

where $\mathrm{BW} x$ is the recorded $\mathrm{BW}$ at age $x, \mathrm{BW} 0=$ the BW at hatching, $\mathrm{iGR}=$ the initial specific growth rate $[(1 / \mathrm{BW} x) \times(\mathrm{dBW} x / \mathrm{d} x)$ when $x \rightarrow 0]$, and $\mathrm{K}=$ the maturation rate or the exponential factor of decay of the specific growth rate.

These parameters were estimated by nonlinear regression with the NLIN procedure (SAS Inst., Inc., Cary, NC), taking into account all available BW from hatching to slaughter. Age at inflection (Ti), at which growth rate is maximal, was calculated as follows:

$$
\mathrm{Ti}=(1 / \mathrm{K}) \ln (|\mathrm{iGR} / \mathrm{K}|)
$$

Individual feed intake (FI) was recorded weekly, and the cumulated FI for the whole rearing period was calculated. The N (NI) and P (PI) intakes for each bird were calculated as the product of $\mathrm{FI}$ and $\mathrm{N}$ and $\mathrm{P}$ concentrations in the diet.

Droppings were individually collected twice a week for the whole rearing period (between 4 and $53 \mathrm{~d}$ of age) using the method of individual total collection of excreta (Bourdillon et al., 1990). Total excreta were weighed and dried to obtain both fresh excreta weight (FEW) and dry

\begin{tabular}{|c|c|c|}
\hline Item & Starter & Grower \\
\hline \multicolumn{3}{|l|}{ Ingredients, as-fed basis } \\
\hline Corn & 60.4 & 60.2 \\
\hline Wheat (Rialto) & 525.0 & 600.0 \\
\hline Soybean meal 48 & 284.0 & 224.5 \\
\hline Corn gluten 60 & 31.0 & 19.0 \\
\hline Soybean oil & 60.0 & 60.0 \\
\hline DL methionine & 1.2 & 0.8 \\
\hline L-Lysine 78 & 2.2 & 2.1 \\
\hline Calcium carbonate & 13.4 & 13.0 \\
\hline Dicalcium phosphate & 15.8 & 13.4 \\
\hline Sodium chloride & 3.0 & 3.0 \\
\hline Mineral and vitamin $\operatorname{mix}^{1}$ & 3.5 & 3.5 \\
\hline Robenidine $^{2}$ & 0.5 & 0.5 \\
\hline \multicolumn{3}{|c|}{ Chemical composition ${ }^{3}$ (as-fed basis) } \\
\hline AMEn, $\mathrm{kcal} / \mathrm{kg}^{1}$ & 2943 & 3002 \\
\hline $\mathrm{CP}, \%$ & 20.5 & 18.4 \\
\hline $\mathrm{Ca}, \%$ & 1.11 & 0.94 \\
\hline tP, $\%$ & 0.66 & 0.60 \\
\hline NPP, $\%$ & 0.42 & 0.37 \\
\hline \multicolumn{3}{|c|}{$\begin{array}{l}{ }^{1} \text { Supplied per kilogram of diet: } 0.5 \mathrm{mg} \mathrm{Co}, 16 \mathrm{mg} \mathrm{Cu}, 47 \mathrm{mg} \mathrm{Fe}, 1.6 \mathrm{mg} \\
\mathrm{I}, 65 \mathrm{mg} \mathrm{Mn}, 0.2 \mathrm{mg} \mathrm{Se}, 72 \mathrm{mg} \mathrm{Zn}, 12,000 \mathrm{IU} \text { retinyl acetate, } 3,440 \mathrm{IU} \\
\text { cholecalciferol, } 80 \mathrm{mg} \text { DL- } \alpha \text { tocopheryl acetate, } 4 \mathrm{mg} \text { thiamine, } 6.4 \mathrm{mg} \\
\text { riboflavin, } 20 \mathrm{mg} \text { calcium pantothenate, } 0.02 \mathrm{mg} \text { vitamin } \mathrm{B} 12,4 \mathrm{mg} \\
\text { menadione, } 5.6 \mathrm{mg} \text { pyridoxine hydrochloride, } 0.4 \mathrm{mg} \text { folic acid, } 0.24 \mathrm{mg} \\
\text { biotin, } 80 \mathrm{mg} \text { niacin, } 440 \mathrm{mg} \text { choline, } 40 \mathrm{mg} \text { antioxidant. }\end{array}$} \\
\hline \multicolumn{3}{|c|}{${ }^{2}$ Robenz, Alpharma Animal Health, Bridgewater, NJ. } \\
\hline
\end{tabular}
excreta weight (DEW) for the whole rearing period. The

Table 1. Diet composition $(\mathrm{g} / \mathrm{kg})$ 
DEW:FI ratio was calculated for the whole rearing period. Freeze-drying was used as it has been found to minimize $\mathrm{N}$ conversion and $\mathrm{NH}_{3}$ loss during processing (Mahimairaja et al., 1990). The water excreta content (WEC) was measured as the difference between FEW and DEW divided by FEW. Three balance trials were performed between 4 and $7 \mathrm{~d}$ (B1), 18 and $21 \mathrm{~d}$ (B2), and 49 and $53 \mathrm{~d}$ (B3) to measure digestibility and $\mathrm{N}$ and $\mathrm{P}$ excretion. Body weight gain (WG)and feed conversion ratio (FCR) were calculated for each balance trial. The AMEn and N excretion (NEx) were measured for all birds using nearinfrared spectrophotometry (NIRS; Foss NIRSystems, Inc., Silver Spring, MD), using the method of Bastianelli et al. (2010). Phosphorus excretion (PE) was measured by colorimetric analysis. The ratios of NEx to PE, NEx to NI, PE to PI, NEx to WG, and PE to WG were calculated for each balance trial.

At 7, 21, and $53 \mathrm{~d}, 16$ birds of each line were euthanized by intracardiac injection of $1.5 \mathrm{~mL} / \mathrm{kg}$ BW of pentobarbital (Sanofi, Marne la Coquette, France). The proventriculus and gizzard were excised, cleaned, and weighed (PRW and GZW, respectively). The small intestine was cut into 3 parts: duodenum (from pylorus to pancreatic loop), jejunum (from the pancreatic loop to Meckel's diverticulum), and ileum (from Meckel's diverticulum to the ileocecal junction). Segment lengths were measured. Segments were then cleaned and weighed (DW, JW, and IW, for duodenum, jejunum, and ileum weights, respectively). The weight to length ratio of each segment (DD, JD, and ID, respectively) was also calculated as an indicator of intestine density (Taylor and Jones, 2004). The ratio of PRW and GZW to small intestine weight (PVG/INT) was calculated as an efficient parameter for predicting AMEn variations (Garcia et al., 2007). All the data regarding organ weight were expressed per kilogram of BW to avoid any confusion between the gastrointestinal tract (GIT)weight trait differences and the potential BW differences between lines. Boluses in the gizzard and ileum were collected, and their $\mathrm{pH}$ was measured with a portable $\mathrm{pH}$ meter (model 506, Crison Instruments, SA, Barcelona, Spain) equipped with a Xerolyte electrode. The right tibia was removed and cleaned of muscle and then stored at $-20^{\circ} \mathrm{C}$ until measurement. After bone defrosting, a 3-point loading test using an Instron Universal Testing Instrument (INSTRON, Guyancourt, France) was employed to measure the bone breaking strength (BBS).

At $24 \mathrm{~h}$ postmortem, the breast meat (Pectoralis major and P. minor) and abdominal fat were excised and weighed for each bird. The breast meat (BMY) and abdominal fat (AFY) yields were calculated. The ultimate $\mathrm{pH}$ of the meat ( $\mathbf{p H u}$ ) was recorded by direct insertion of the Xerolyte electrode into the muscle. Breast meat color was measured at $24 \mathrm{~h}$ postslaughter using a
Miniscan spectrocolorimeter (Hunterlab, Reston, VA) CIE L*a*b* system, where $\mathrm{L}^{*}$ represents the lightness, $a^{*}$ is the redness, and $b^{*}$ is the yellowness of the meat; greater $\mathrm{L}^{*}, \mathrm{a}^{*}$, and $\mathrm{b}^{*}$ values correspond to paler, redder, and yellower meat, respectively.

\section{Statistical Analyses}

All data were analyzed according to the General Linear Models (GLM) procedure of SAS, including a line effect, with all other effects being nonsignificant. For $\mathrm{BW}$, sex effect was significant and thus was included in the model. Homogeneity of variances was not respected between groups because of a greater variance of D- birds. Analyses of variance were thus weighted by inverse of variance of each group. Differences were considered significant when the $P$-value was less than 0.05 .

\section{RESULTS}

The elementary statistics for growth curve parameters, cumulated feed consumption, feed efficiency, and cumulated excretion characteristics for the whole rearing period (from hatching to $53 \mathrm{~d}$ of age) for both $\mathrm{D}+$ and $\mathrm{D}$ - and the RL are reported in Table 2. Weekly analyses are reported in Figs. 1 and 2 and Table 3.

The selection criterion (AMEn) was always 4.6\% to $25.0 \%$ greater $(P<0.05)$ in $\mathrm{D}+$ than in $\mathrm{D}$ - whatever the age considered, with the difference being greatest at 3 wk (i.e., age for the selection experiment). The RL was intermediate, closer to $\mathrm{D}+$ than $\mathrm{D}$-, with differences being significant $(P<0.05)$ at $3 \mathrm{wk}$ but not at 1 and $7 \mathrm{wk}$ ( $P=0.06$ and $P=0.07$, respectively).

Whatever the age, D- birds consumed $20.6 \%$ to $55.9 \%$ more $(P<0.05)$ feed than $\mathrm{D}+$ birds. When compared with the RL line, D- birds still had a $12.6 \%$ to $38.2 \%$ greater FI, but only from 21 to $53 \mathrm{~d}$. Furthermore, FI was greater $(P<0.05)$ in RL than in $\mathrm{D}+$ birds between 7 and $42 \mathrm{~d}$, with the former consuming $9.2 \%$ to $30.4 \%$ more than the latter.

Body weight was greater $(P<0.05)$ in RL birds than in $\mathrm{D}+$ and $\mathrm{D}$ - birds until $42 \mathrm{~d}$, but the difference did not continue after this age, with all 3 lines reaching similar $\mathrm{BW}$ at $53 \mathrm{~d}$. Moreover, the line effect was not significant for the growth curve parameters. As a result of FI and growth differences, the FCR for D- birds was 131.2\% greater $(P<0.05)$ than $\mathrm{D}+$ between 17 and $42 \mathrm{~d}$ of age. The FCR of $\mathrm{D}+$ was also $14.3 \%$ to $22.3 \%$ less than $(P<$ $0.05)$ in the RL line between 7 and $28 \mathrm{~d}$. After $42 \mathrm{~d}$, the FCR did not differ between the 3 lines. As a result, the FCR over the whole rearing period was less $(P<0.05)$ in $\mathrm{D}+(2.00)$ than in $\mathrm{D}$ - (2.93) line.

With regard to manure characteristics, $\mathrm{D}+$ birds excreted less $(P<0.05)$ fresh and dry excreta than 
D- birds, whatever the age, from $36.2 \%$ to $83.8 \%$ for fresh and from $40.0 \%$ to $76.3 \%$ for dry excreta weight, with the difference being greater between 21 and 35 d. The specific increase in FI, FCR, FEW, FEW/FI, DEW, and DEW/FI observed at 3 wk of age in D- birds corresponded to the age of selection. At the same time, birds were transferred from their initial room to another, which can partly explain the greater difference.

The RL birds were intermediate but produced $13.2 \%$ to $66.2 \%$ less fresh and $19.7 \%$ to $63.2 \%$ less dry excreta than D- birds. For all measurements, the greatest differences were observed between 21 and 35 d (i.e., around the selection age). Furthermore, except between 42 and $49 \mathrm{~d}, \mathrm{D}+$ birds produced $17.2 \%$ to $41.6 \%$ less $(P<0.05)$ dry excreta than RL birds, and the differences decreased with the age. The differences between $\mathrm{D}+$ and RL birds were not significant for fresh excreta weight.

For the whole rearing period, the cumulated fresh excreta weight was reduced $(P<0.05)$ by $56.2 \%$ in $\mathrm{D}+$ and by $53.3 \%$ in RL birds compared with D- birds. The total production of dry excreta was, in turn, reduced $(P<0.05)$ in $\mathrm{D}+$ birds by $26.3 \%$ compared with $\mathrm{RL}$ birds and by $61.2 \%$ compared with D- birds. This difference between results for fresh and dry excreta was related to a significantly $(P<0.05)$ different water content (WC) of excreta between lines. Water content was greater for $\mathrm{D}+$ than $\mathrm{D}$-, with the differences being significant around the selection age (i.e., between 14 and $28 \mathrm{~d}$ ). The RL birds had the lowest WC and differed significantly from $\mathrm{D}+$ birds from 14 to $49 \mathrm{~d}$.

When excretion weights were corrected for FI to take into account the FI differences between lines, the results were similar, with D- birds excreting significantly more fresh excreta than RL and $\mathrm{D}+$ and the dry excreta weights in relation to FI for the
3 genotypes being significantly $(P<0.05)$ different from each other. For excretion traits, NEx/NI was $15.1 \%$ less $(P<0.05)$ in $\mathrm{D}+$ than in the RL line during B1, but RL did not differ from D-. Similarly, during B1, D+ birds had $15.7 \%$ and $18.4 \%$ less $(P<0.05) \mathrm{P}$ excretion rates than D- and RL, respectively, with the last 2 being not different. During B2, NEx/NI and PE/ PI were $17.5 \%$ to $30.0 \%$ less in $\mathrm{D}+$ than in $\mathrm{D}$ - and $\mathrm{RL}$ birds. As for AMEn, the greatest differences between lines were observed at $3 \mathrm{wk}$. Finally, NEx/PE was 7.5\% less $(P<0.05)$ in $\mathrm{D}$ - than in $\mathrm{D}+$ birds during $\mathrm{B} 1$ but $16.2 \%$ greater during $\mathrm{B} 2$. The $\mathrm{NEx} / \mathrm{PE}$ ratio for $\mathrm{RL}$ birds did not differ from $\mathrm{D}$ - and $\mathrm{D}+$ during $\mathrm{B} 1$. During B2, RL birds differed significantly from D- birds, with the NEx/PE ratio being $8.2 \%$ less than in D- birds. During B3, the ranking was the same, but differences between lines were not significant. Excretion of $\mathrm{N}$ and $\mathrm{P}$ in relation to $\mathrm{WG}$ differed significantly $(P<0.05)$ between the 3 lines at selection age, with $\mathrm{D}+$ excreting $28.6 \%$ less $\mathrm{P}$ and $33.0 \%$ less $\mathrm{N}$ per gram of $\mathrm{WG}$ than $\mathrm{RL}$ birds and $43.7 \%$ and $51.4 \%$ less $\mathrm{P}$ and $\mathrm{N}$ than D- birds. Differences in PE/WG between lines were already present at $1 \mathrm{wk}$, with $\mathrm{D}+$ showing reduced excretion compared with the other 2 lines $(-10.5 \%$ and $-18.4 \%$ when compared with RL and D-, respectively). At this age, $\mathrm{D}+$ also excreted $12.1 \%$ less $(P<0.05) \mathrm{N}$ per gram of WG than D- birds. At $7 \mathrm{wk}$, there was no longer a significant difference between lines in NE/WG and PE/ WG.

Gastrointestinal tract morphology is shown in Table 4. The relative PRW was $13.9 \%$ and $71.2 \%$ greater $(P<0.05)$ in $\mathrm{D}+$ birds than in RL birds at 7 and $21 \mathrm{~d}$, respectively, but the difference did not persist at $53 \mathrm{~d}$. D- birds presented intermediate values at all ages. Relative gizzard weight was greater in $\mathrm{D}+$ birds than in RL at all ages. Relative gizzard weight was also

Table 2. Basic statistics (least squares means $\pm \mathrm{SE}$ ) for BW at $53 \mathrm{~d}$, growth curve parameters, feed intake, feed conversion ratio, and excretion characteristics for the whole rearing period for each line ( $n$ ranging from 42 to 47 )

\begin{tabular}{|c|c|c|c|c|c|c|c|}
\hline \multirow[b]{2}{*}{ Variable $^{1}$} & \multirow[b]{2}{*}{$\mathrm{D}+$} & \multirow[b]{2}{*}{ D- } & \multirow[b]{2}{*}{ RL } & \multirow[b]{2}{*}{ SEM } & \multicolumn{3}{|c|}{ Line effect ${ }^{2}$} \\
\hline & & & & & D+ vs. D- & $\mathrm{D}+$ vs. $\mathrm{RL}$ & D- vs. RL \\
\hline BW53, g & 1,974 & 1,893 & 1,989 & 281 & NS & NS & NS \\
\hline $\mathrm{K}, \mathrm{L} / \mathrm{d}$ & 0.038 & 0.038 & 0.041 & 0.004 & NS & NS & NS \\
\hline Ti, d & 41.6 & 40.9 & 39.2 & 5.99 & NS & NS & NS \\
\hline FI, $g$ & 4,544 & 6,150 & 5,032 & 1,509 & $*$ & $*$ & $*$ \\
\hline DEW, g & 897 & 2309 & 1217 & 1169 & $*$ & $*$ & $*$ \\
\hline FEW/FI, g/g & 0.67 & 1.07 & 0.64 & 0.104 & $*$ & NS & $*$ \\
\hline DEW/FI g/g & 0.24 & 0.43 & 0.29 & 3.08 & $*$ & $*$ & $*$ \\
\hline WC, \% & 68.9 & 66.4 & 62.7 & 0.33 & NS & * & * \\
\hline
\end{tabular}

${ }^{1} \mathrm{BW} 53=\mathrm{BW}$ at $53 \mathrm{~d} ; \mathrm{iGR}=$ initial specific growth rate; $\mathrm{K}=$ maturation rate; $\mathrm{Ti}=$ age of inflection; FI = feed intake; FCR = feed conversion ratio; FEW and $\mathrm{DEW}=$ fresh and dry excreta weight; FEW/FI and DEW/FI $=$ fresh and dry excreta weight relative to feed intake; $\mathrm{WC}=$ water excreta content.

${ }^{2} \mathrm{NS}=P>0.05 ; *=P<0.05$. 
significantly greater in $\mathrm{D}+$ than in $\mathrm{D}-$ at 7 and $21 \mathrm{~d}(P$ $=0.07$ at $53 \mathrm{~d})$ but lighter $(P<0.05)$ in RL compared with D- at $7 \mathrm{~d}$ of age. Relative intestinal segment weights were similar in D+ and RL birds at 7 and $53 \mathrm{~d}$, except for DW at $7 \mathrm{~d}$, but D+ had a $23.3 \%$ and $23.2 \%$ lighter $(P<0.05)$ jejunum and ileum, respectively, than RL birds at $21 \mathrm{~d}$. Furthermore, D+ birds had less dense $(P<0.05)$ intestines than RL birds whatever the age, with differences ranging from $15.9 \%$ to $34.5 \%$. D + also had $12.0 \%$ to $30.8 \%$ lighter and $16.7 \%$ to $25.0 \%$ less dense intestines than D- birds at 21 and $53 \mathrm{~d}$. Finally, intestinal weights of D- and RL birds did not differ from

a)

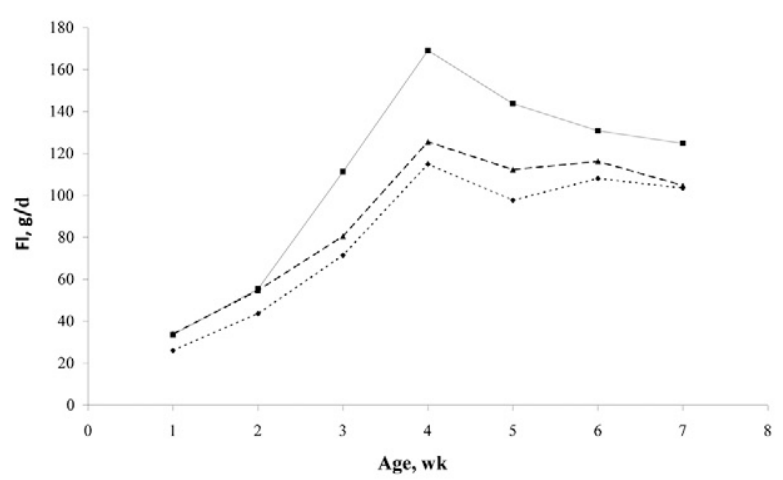

b)

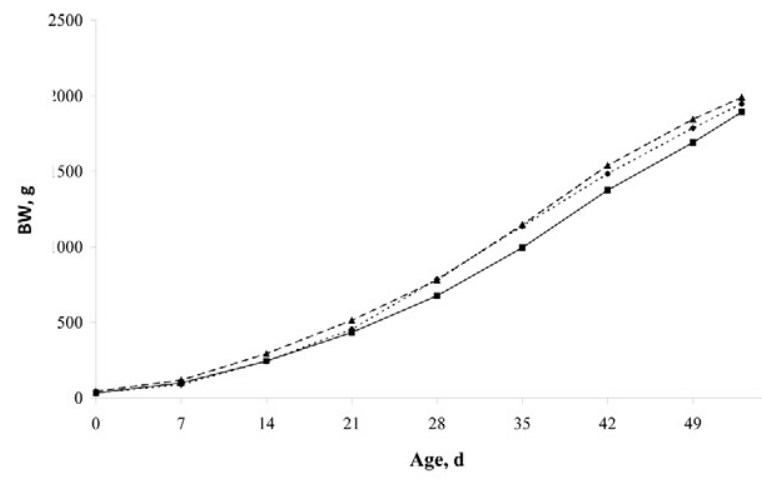

c)

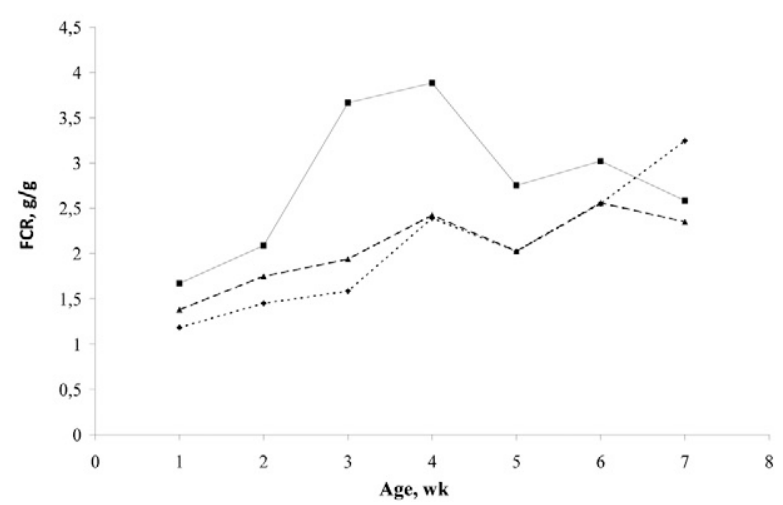

Figure 1. Effect of divergent line (D+, dotted line, and D-, solid line) and reference line (CL, dashed line) on (a) feed intake (FI), (b) BW, and (c) feed conversion ratio (FCR) for each rearing week. $\mathrm{D}+$ : line selected for high AMEn; D-: line selected for low AMEn; RL: reference line each other at 7 and $21 \mathrm{~d}$, and densities did not differ at any age, except for IW at $7 \mathrm{~d}$ and JD at $21 \mathrm{~d}$. The weights of intestinal segments were heavier in D- than in RL birds at $53 \mathrm{~d}$. The differences in the development of the upper and lower parts of the GIT resulted in greater $\mathrm{PVG} / \mathrm{INT}$ ratio values in $\mathrm{D}+$ birds than in $\mathrm{RL}$ and D- birds at all ages, with differences being not significant between D- and RL birds. Differences were greatest at $21 \mathrm{~d}$, with values for $\mathrm{D}+$ birds being twice as high as for RL and D- at this age. Finally, the $\mathrm{pH}$ of gizzard content was lower $(P<0.05)$ in $\mathrm{D}+$ than in $\mathrm{D}-$ and RL birds at $21 \mathrm{~d}$. The $\mathrm{pH}$ of ileum content was higher $(P<0.05)$ in $\mathrm{D}+$ birds than in $\mathrm{D}$ - birds at 21 and $53 \mathrm{~d}$, but lower than in RL birds at $7 \mathrm{~d}$.

Body composition (BMY and AFY) and BBS at 7, 21 , and $53 \mathrm{~d}$ are shown in Table 5. The ranking of lines for BMY and AFY changed with age, with $\mathrm{D}+$ birds having $18.4 \%$ and $22.4 \%$ less $(P<0.05)$ BMY than Dand RL birds at $7 \mathrm{~d}$, respectively, but $8.32 \%$ greater $(P<$ $0.05)$ BMY than D- birds at $53 \mathrm{~d}$. At $53 \mathrm{~d}$, AFY was less in RL and D+ birds than in D- birds, but RL were fatter than $\mathrm{D}+$ and $\mathrm{D}$ - birds at $21 \mathrm{~d}$.

Meat color characteristics ( $\mathrm{L}^{*}, \mathrm{a}^{*}$, and $\left.\mathrm{b}^{*}\right)$ at $53 \mathrm{~d}$ are shown in Table 6 . The pHu was $1.06 \%$ higher $(P<$ $0.05)$ in RL than in D+. Meat color was not significantly different between the 3 lines.

The BBS was greater $(P<0.05)$ in RL than in Dbirds at 7 and $21 \mathrm{~d}$, but the difference was not found at $53 \mathrm{~d}$.

\section{DISCUSSION}

As expected, $\mathrm{D}+$ birds showed significantly greater AMEn values for the 3 balance trials than D- birds, which was consistent with previous studies at $23 \mathrm{~d}$ of age (Mignon-Grasteau et al., 2004; de Verdal et al., 2011b). They had also greater AMEn than RL birds at 7 and $21 \mathrm{~d}$. Compared with the selection of the RL based on commercial traits, it turns out that the selection for AMEn deteriorated the digestibility in D- birds more strongly than it improved it in $\mathrm{D}+$ birds. This observation can be easily explained by the fact that starch digestibility nearly reached the maximum value of $100 \%$ (i.e., $96.3 \%$ in D+ vs. $88.4 \%$ in D- birds; MignonGrasteau et al., 2004), reducing the improvement margin regarding feed digestibility in $\mathrm{D}+$. In addition, it should be noticed that in contrary to the phenotypic values, the evolution of the genetic values between the divergent lines was symmetric.

The differences were greatest at 3 wk for most traits, which could be expected as 3 wk corresponds to selection age. Differences could probably be increased further by also selecting for AMEn when older, although the additional progress that could be expected would 
probably be smaller. Indeed, AMEn is strongly linked to the development of the GIT, which is greatest during the first weeks of bird life (Palo et al., 1995). This assumption was consistent with the high genetic correlations between AMEn and gizzard and intestine weights (de Verdal et al., 2011a). The secreting and grinding activity of the proventriculus and gizzard increase with their weight (Svihus, 2011), which improves nutrient availability in the small intestine and thus digestibility ( $\mathrm{Wu}$ and Ravindran, 2004). Our results indicated that $\mathrm{D}+$ birds presented greater development of the upper part of the GIT at $7 \mathrm{~d}$ compared with D- and RL birds, which could

a)

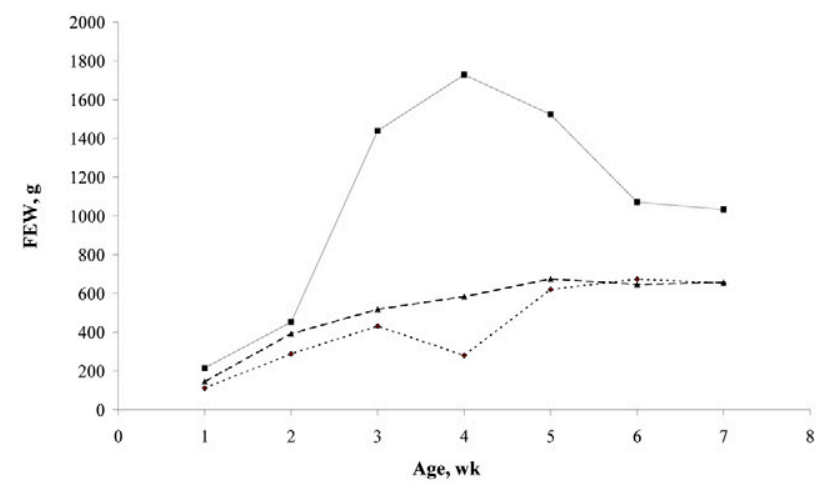

b)

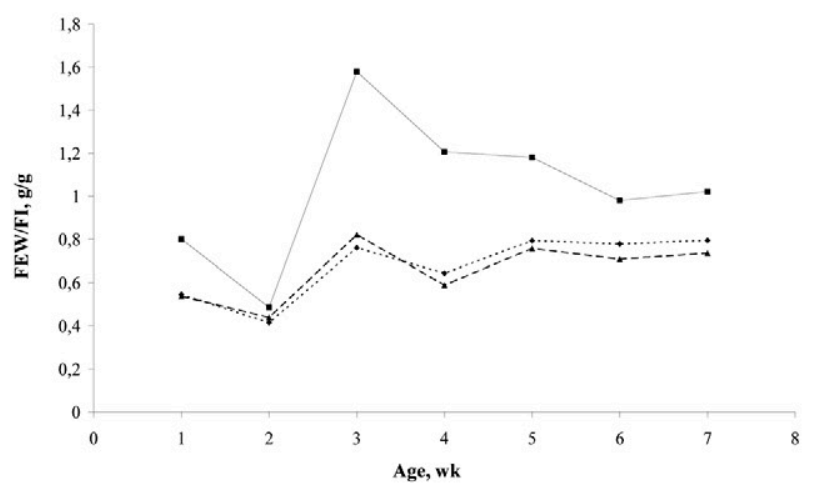

be explained by a greater sensitivity of the $\mathrm{D}+$ to a wheatbased diet. In contrast, differences between lines in the weight of the lower part of the GIT appeared more marked at 21 and $53 \mathrm{~d}$, which was consistent with the hypothesis that the development of the intestine occurs in response to the development of the gizzard and proventriculus (de Verdal et al., 2010). These differences resulted in a greater PVG/INT ratio in D+ than in D- and RL birds at all ages, which was consistent with previous results (Rougière et al., 2009) in which this ratio was considered as a relevant predictor of digestion efficiency in broilers. Until $42 \mathrm{~d}$ of age, D+ and D- birds presented a lighter BW than RL birds,

c)

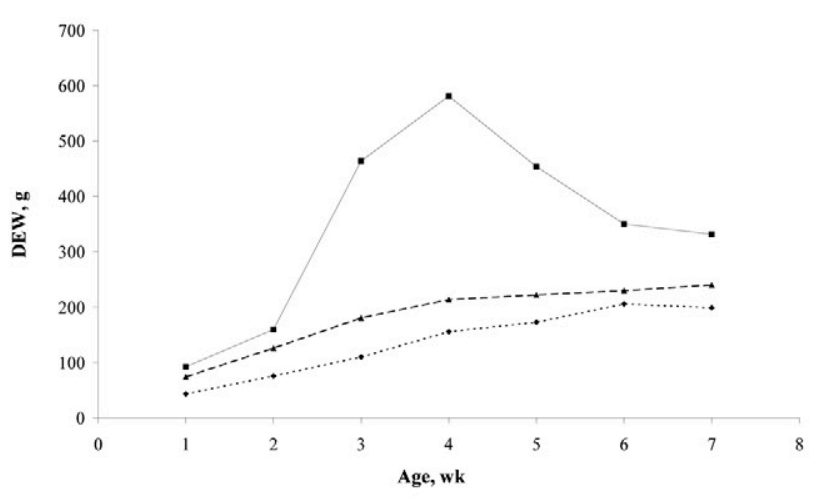

d)

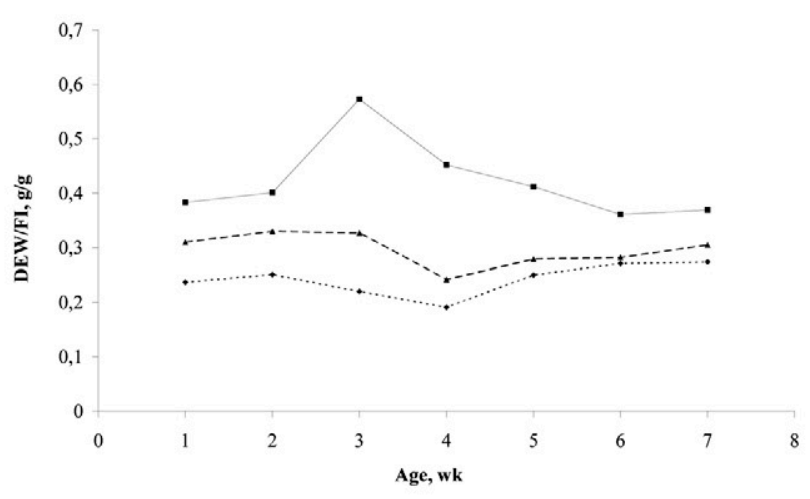

e)

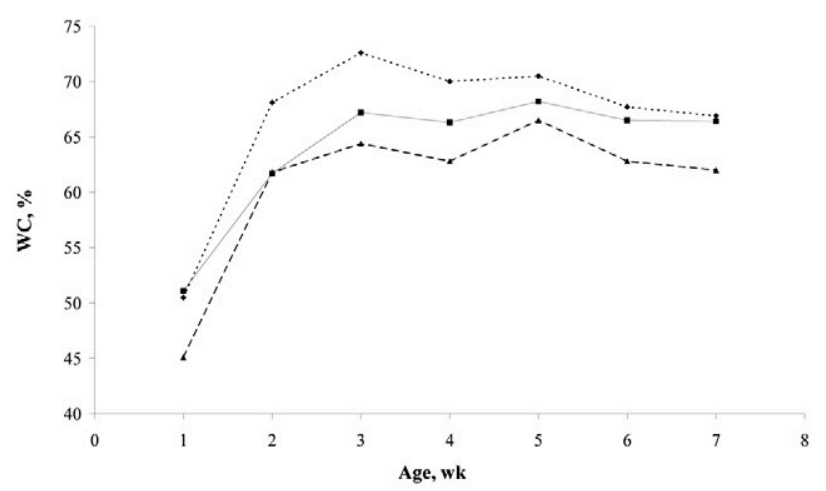

Figure 2. Effect of divergent line (D+, dotted line, and D-, solid line) and reference line (CL, dashed line) on (a) fresh excreta weight (FEW), (b) fresh excreta weight:feed intake (FEW:FI), (c) dry excreta weight (DEW), (d) dry excreta weight:feed intake (DEW/FI), and (e) water content (WC) for each rearing week. D+: line selected for high AMEn; D-: line selected for low AMEn; RL: reference line. 
Table 3. Basic statistics (least squares means $\pm \mathrm{SE}$ ) for AMEn and excretion composition, NE/NI, NE/WG, PE/PI, PE/ $\mathrm{WG}$, and NE/PE, performed at each balance trial for each line ${ }^{1}$

\begin{tabular}{|c|c|c|c|c|c|c|c|}
\hline$\overline{\mathrm{Age}^{2}}$ & Line & AMEn & $\mathrm{NE} / \mathrm{NI}$ & NE/WG & $\mathrm{PE} / \mathrm{PI}$ & $\mathrm{PE} / \mathrm{WG}$ & $\mathrm{NE} / \mathrm{PE}$ \\
\hline \multirow[t]{7}{*}{$\overline{\mathrm{B} 1}$} & $\mathrm{D}+$ & 3502 & 0.28 & 15.24 & $0.26 \pm 0.01$ & $2.19 \pm 0.06$ & $7.04 \pm 0.15$ \\
\hline & D- & 3347 & 0.32 & 17.3 & $0.31 \pm 0.01$ & $2.69 \pm 0.06$ & $6.51 \pm 0.15$ \\
\hline & $\mathrm{RL}$ & 3397 & 0.33 & 16.1 & $0.32 \pm 0.01$ & $2.45 \pm 0.07$ & $6.61 \pm 0.15$ \\
\hline & SEM & 197 & 0.07 & 2.96 & 0.07 & 0.50 & 0.70 \\
\hline & $\mathrm{D}+$ vs. $\mathrm{D}^{3}{ }^{3}$ & $*$ & $\mathrm{NS}(P=0.08)$ & $*$ & $*$ & $*$ & $*$ \\
\hline & $\mathrm{D}+$ vs. $\mathrm{RL}$ & $\mathrm{NS}(P=0.06)$ & * & NS & * & $*$ & NS \\
\hline & D- vs. RL & NS & NS & NS & NS & * & NS \\
\hline \multirow[t]{7}{*}{ B2 } & $\mathrm{D}+$ & 3229 & 0.42 & 19.7 & 0.47 & 3.60 & 5.49 \\
\hline & D- & 2583 & 0.60 & 40.5 & 0.63 & 6.40 & 6.38 \\
\hline & RL & 3038 & 0.51 & 29.4 & 0.57 & 5.04 & 5.86 \\
\hline & SEM & 462 & 0.08 & 13.2 & 0.10 & 2.07 & 0.71 \\
\hline & D+ vs. D- & $*$ & $*$ & $*$ & $*$ & $*$ & $*$ \\
\hline & $\mathrm{D}+$ vs. RL & $*$ & $*$ & $*$ & $*$ & $*$ & $\mathrm{NS}(P=0.06)$ \\
\hline & D- vs. RL & * & * & * & NS & * & $*$ \\
\hline \multirow[t]{7}{*}{ B3 } & $\mathrm{D}+$ & 3,073 & 0.58 & 59.6 & 0.59 & 9.24 & 5.03 \\
\hline & D- & 2,730 & 0.73 & 58.1 & 0.68 & 10.6 & 5.54 \\
\hline & $\mathrm{RL}$ & 2,966 & 0.66 & 38.4 & 0.66 & 7.75 & 5.12 \\
\hline & SEM & 222 & 0.10 & 15.8 & 0.13 & 3.35 & 0.75 \\
\hline & D+ vs. D- & $*$ & $*$ & NS & NS & NS & NS \\
\hline & $\mathrm{D}+$ vs. $\mathrm{RL}$ & NS & NS & NS & NS & NS & NS \\
\hline & D- vs. RL & $*$ & NS & NS & NS & NS & NS \\
\hline
\end{tabular}

${ }^{1} \mathrm{AMEn}=$ apparent ME corrected for $0 \mathrm{~N}$ retention $\left(\mathrm{kcal} \cdot \mathrm{kgMS}^{-1}\right) ; \mathrm{NE} / \mathrm{NI}$ and $\mathrm{PE} / \mathrm{PI}=\mathrm{N}$ and $\mathrm{P}$ excreted relative to $\mathrm{N}$ and $\mathrm{P}$ intake $(\mathrm{g} / \mathrm{g}) ; \mathrm{NE} / \mathrm{WG}$ and $\mathrm{PE} / \mathrm{WG}=\mathrm{N}$ and $\mathrm{P}$ excreted relative to $\mathrm{BW}$ gain $(\mathrm{g} / \mathrm{kg}) ; \mathrm{NE} / \mathrm{PE}=\mathrm{N}$ excreted relative to $\mathrm{P}$ excreted $(\mathrm{g} / \mathrm{g})$.

${ }^{2} \mathrm{~B} 1$ : from 4 to 7 days of age, B2: from 18 to 21 days of age and B3: from 49 to 53 days of age.

${ }^{3} \mathrm{NS}=P>0.05 ; *=P<0.05$.

Table 4. Basic statistics (least squares means $\pm \mathrm{SE}$ ) for all the measures of the gastrointestinal tract morphology for each line and age of slaughter ${ }^{1}$

\begin{tabular}{|c|c|c|c|c|c|c|c|c|c|c|c|c|}
\hline Age, d & Line & PRW & GZW & DW & JW & IW & PVG/INT & $\mathrm{DD}$ & JD & ID & $\mathrm{pH}$ gizzard & $\mathrm{pH}$ ileum \\
\hline \multirow[t]{5}{*}{7} & $\mathrm{D}+$ & 11.5 & 46.3 & 18.8 & 23.1 & 16.0 & 1.00 & 0.11 & 0.07 & 0.05 & 3.55 & 7.46 \\
\hline & D- & 10.7 & 40.3 & 14.8 & 25.1 & 17.8 & 0.89 & 0.12 & 0.09 & 0.07 & 3.46 & 7.39 \\
\hline & SEM & 1.44 & 4.88 & 2.39 & 4.20 & 2.29 & 0.11 & 0.15 & 0.015 & 0.021 & 0.20 & 0.26 \\
\hline & $\mathrm{D}+$ vs. $\mathrm{D}-{ }^{2}$ & NS & $*$ & $*$ & NS & $\mathrm{NS}(P=0.10)$ & $*$ & NS & $*$ & * & NS & NS \\
\hline & $\mathrm{D}+$ vs. RL & * & * & $*$ & NS & NS & $*$ & $\mathrm{NS}(P=0.06)$ & $*$ & * & NS & $*$ \\
\hline \multirow{5}{*}{21} & D- & 6.86 & 17.9 & 14.2 & 24.9 & 18.2 & 0.43 & 0.30 & 0.25 & 0.20 & 3.92 & 6.91 \\
\hline & RL & 5.84 & 15.9 & 13.3 & 23.6 & 16.4 & 0.41 & 0.30 & 0.29 & 0.21 & 3.97 & 7.18 \\
\hline & SEM & 1.77 & 4.47 & 1.67 & 2.91 & 2.85 & 0.08 & 0.03 & 0.03 & 0.03 & 0.51 & 0.35 \\
\hline & D+ vs. D- & * & $*$ & $*$ & * & $*$ & * & * & $*$ & * & $*$ & $*$ \\
\hline & $\mathrm{D}+$ vs. $\mathrm{RL}$ & $*$ & $*$ & NS & * & $*$ & $*$ & * & $*$ & $*$ & $*$ & $*$ \\
\hline \multirow{5}{*}{53} & RL & 2.74 & 9.71 & 5.64 & 11.2 & 8.99 & 0.49 & 0.44 & 0.38 & 0.31 & 5.24 & 7.46 \\
\hline & SEM & 0.79 & 1.36 & 1.18 & 1.99 & 1.71 & 0.08 & 0.08 & 0.08 & 0.06 & 0.65 & 0.22 \\
\hline & D+ vs. D- & NS & $\mathrm{NS}(P=0.09)$ & $*$ & * & $*$ & $*$ & * & $*$ & * & NS & $*$ \\
\hline & $\mathrm{D}+\mathrm{vs} . \mathrm{RL}$ & NS & $*$ & NS & NS & NS & $*$ & * & $*$ & $*$ & $\mathrm{NS}(P=0.07)$ & NS \\
\hline & D- vs. RL & NS & NS & $*$ & * & $*$ & NS & NS & NS & NS & NS & $\mathrm{NS}(P=0.07)$ \\
\hline
\end{tabular}

${ }^{1} \mathrm{PRW}=$ proventriculus weight relative to $\mathrm{BW}(\mathrm{g} / \mathrm{kg}) ; \mathrm{GZW}=$ gizzard weight relative to $\mathrm{BW}(\mathrm{g} / \mathrm{kg}) ; \mathrm{DW}$, JW, and IW = duodenum, jejunum, and ileum weights relative to $\mathrm{BW}(\mathrm{g} / \mathrm{kg}) ; \mathrm{PVG} / \mathrm{INT}=$ proventriculus and gizzard weight relative to small intestine weight $(\mathrm{g} / \mathrm{g})$; DD, JD, and ID = duodenum, jejunum, and ileum density $(\mathrm{g} / \mathrm{cm}) ; \mathrm{pH}$ gizzard and $\mathrm{pH}$ ileum $=\mathrm{pH}$ measurements of the content of the gizzard and ileum compartments.

${ }^{2} \mathrm{NS}=P>0.05 ; *=P<0.05$. 
but the differences were not maintained at $53 \mathrm{~d}$ of age. However, the final BW of D- was achieved with 35.3\% and $22.2 \%$ greater FI than D+ and RL birds, respectively. For the same BW at $53 \mathrm{~d}, \mathrm{D}+$ birds consumed $488 \mathrm{~g}$ less feed than RL birds. Consequently, for a poultry farm of 20,000 chickens, 9.76 tons of feed could be saved for each hatch if rearing $\mathrm{D}+$ birds rather than RL birds, and that amount is not negligible in terms of saving natural resources.

Mignon-Grasteau et al. (2010b) and de Verdal et al. (2011b) showed that D- birds excreted $70.2 \%$ and $117.6 \%$ more FEW and DEW, respectively, at $3 \mathrm{wk}$ than D+ birds. In the present study, D- birds excreted $73.4 \%$ and $98.7 \%$ more FEW and DEW than D+ birds during B2, which was consistent with previous results. These differences were intensified if we took into account the whole rearing period, with $128 \%$ and $157 \%$ greater FEW and DEW for D- than for D+ birds. These substantial differences between lines were probably at least partly linked to variations in FI between genotypes. Indeed, when correcting DEW for FI, excretion of the $\mathrm{D}+$ birds was $44.2 \%$ and $17.4 \%$ less than D- and RL birds, respectively. The fact that differences between $\mathrm{D}+$ and RL birds were significant for dry excreta but not for fresh excreta weights could be explained by the $9.9 \%$ greater water content in the excreta of $\mathrm{D}+$ than in $\mathrm{RL}$ birds for the whole rearing period. This greater

Table 5. Basic statistics (least squares means \pm SE) for BMY, AFY, and BBS for each line and age of slaughter ${ }^{1}$

\begin{tabular}{|c|c|c|c|c|}
\hline Age, d & Line & BMY & AFY & BBS \\
\hline \multirow[t]{7}{*}{7} & $\mathrm{D}+$ & 2.49 & 0.28 & 18.8 \\
\hline & D- & 3.05 & 0.31 & 18.3 \\
\hline & RL & 3.21 & 0.40 & 22.0 \\
\hline & SEM & 0.46 & 0.12 & 3.10 \\
\hline & $\mathrm{D}+$ vs. D- ${ }^{2}$ & $*$ & NS & NS \\
\hline & $\mathrm{D}+$ vs. $\mathrm{RL}$ & $*$ & $*$ & $\mathrm{NS}(P=0.06)$ \\
\hline & D- vs. RL & NS & NS & $*$ \\
\hline \multirow[t]{7}{*}{21} & $\mathrm{D}+$ & 5.15 & 1.11 & 90.5 \\
\hline & D- & 5.16 & 1.06 & 79.2 \\
\hline & RL & 5.09 & 1.85 & 108 \\
\hline & SEM & 0.53 & 0.52 & 24.4 \\
\hline & D+ vs. D- & NS & NS & NS \\
\hline & $\mathrm{D}+\mathrm{vs} . \mathrm{RL}$ & NS & $*$ & $\mathrm{NS}(P=0.08)$ \\
\hline & D- vs. RL & NS & $*$ & $*$ \\
\hline \multirow[t]{7}{*}{53} & $\mathrm{D}+$ & 6.25 & 3.94 & 227 \\
\hline & D- & 5.77 & 4.61 & 206 \\
\hline & RL & 6.38 & 3.87 & 222 \\
\hline & SEM & 0.30 & 0.64 & 53.2 \\
\hline & D+ vs. D- & $*$ & $*$ & NS \\
\hline & $\mathrm{D}+\mathrm{vs} . \mathrm{RL}$ & NS & NS & NS \\
\hline & D- vs. RL & $*$ & $*$ & NS \\
\hline
\end{tabular}

${ }^{1} \mathrm{BMY}=$ breast meat yield $(\%) ; \mathrm{AFY}=$ abdominal fat yield $(\%) ; \mathrm{BBS}=$ bone breaking strength $(\mathrm{N})$.

${ }^{2} \mathrm{NS}=P>0.05 ; *=P<0.05$.
WC of D+ birds had already been found at $3 \mathrm{wk}$ (de Verdal et al., 2011b) and suggests that litter from D+ birds would be wetter than litter from D- or RL birds, thus increasing the risks of ammonia emissions (Miles et al., 2011). Excreta also differed in composition because $\mathrm{N}$ and $\mathrm{P}$ excretion rates were significantly different between the 3 lines. The $\mathrm{D}+$ birds excreted significantly less $\mathrm{N}$ and $\mathrm{P}$ for the same $\mathrm{BW}$ gain during $\mathrm{B} 1$ and $\mathrm{B} 2$ than $\mathrm{D}-$ and RL birds, with greater $\mathrm{N}$ and $\mathrm{P}$ use efficiency. Over the whole rearing period, D+, D-, and RL birds excreted 53.7, 111.1, and $64.4 \mathrm{~g}$ of $\mathrm{N}$ and $9.77,18.8$, and $11.4 \mathrm{~g}$ of $\mathrm{P}$, respectively. For a poultry house of 20,000 chickens, rearing D+ birds instead of RL birds would therefore result in a reduction of 215 and $31.9 \mathrm{~kg}$ of $\mathrm{N}$ and $\mathrm{P}$ excreted in litter, respectively (i.e., -968.4 and $-143.6 \mathrm{~kg}$ of $\mathrm{N}$ and $\mathrm{P}$ per year at 4.5 hatches per year, which is the usual number of hatches for this type of chicken). Taking into account European regulations for spreading $\mathrm{N}$ and $\mathrm{P}(170 \mathrm{~kg}$ of $\mathrm{N} \cdot \mathrm{ha}^{-1} \cdot \mathrm{yr}^{-1}$ and $80 \mathrm{~kg} \mathrm{P} \mathrm{O}_{5} \cdot \mathrm{ha}^{-1} \cdot \mathrm{yr}^{-1}$ ) and the fact that around $50 \%$ of $\mathrm{N}$ is lost between excretion and spreading (ammonia volatilization), 14.2, 29.4, and 17.1 ha would be required to spread $\mathrm{N}$ and 25.2, 48.5, and 29.3 ha would be required to spread P for D+, D-, and RL chicken farms, respectively.

Poultry manure had an average N/P ratio of 2 (Gilbertson et al., 1979; Sharpley, 1999), whereas the $\mathrm{N} / \mathrm{P}$ requirement of most crops is almost 8 (White and Collins, 1982; Moore et al., 1995). However, most fields have an excess of $\mathrm{N}$ and $\mathrm{P}$ in the soil, mainly because of repeated manure application over many years. According to the French and European regulations, the ideal N/P ratio when manure is spread on fields is 2.13 , which is far below the crop requirements. Taking into account the litter and the water part of the manure spread (Institut Technique de l'Aviculture, 2001) and also the volatilization of $\mathrm{NH}_{3}$, the $\mathrm{N} / \mathrm{P}_{2} \mathrm{O}_{5}$ ratio found in the manure in the present study ranged from 1.04 to 1.50 . The proportion of $\mathrm{P}_{2} \mathrm{O}_{5}$ compared with $\mathrm{N}$ was thus unbalanced. Nitrogen loss should be limited to improve the balance between $\mathrm{N}$ and $\mathrm{P}$ in manure. This

Table 6. Basic statistics (least squares means \pm SE) for breast meat and bone quality traits for each line at 53 d of age

\begin{tabular}{lccccccc}
\hline \hline & & & & & \multicolumn{3}{c}{ Line effect $^{2}$} \\
\cline { 6 - 8 } Trait & & $\mathrm{D}+$ & $\mathrm{D}-$ & $\mathrm{RL}$ & $\mathrm{SEM}$ & $\mathrm{D}+$ vs. D- D+ vs. $\mathrm{RL}^{2}$ & $\mathrm{D}-\mathrm{vs} . \mathrm{RL}$ \\
\hline $\mathrm{L}^{*}$ & 47.2 & 48.9 & 47.3 & 3.41 & $\mathrm{NS}$ & $\mathrm{NS}$ & $\mathrm{NS}$ \\
$\mathrm{a}^{*}$ & 0.41 & -0.30 & 0.06 & 1.60 & $\mathrm{NS}$ & $\mathrm{NS}$ & $\mathrm{NS}$ \\
$\mathrm{b}^{*}$ & 12.9 & 11.4 & 11.5 & 2.65 & $\mathrm{NS}$ & $\mathrm{NS}$ & $\mathrm{NS}$ \\
$\mathrm{pHu}$ & 5.69 & 5.69 & 5.75 & 0.11 & $\mathrm{NS}$ & $*$ & $\mathrm{NS}$ \\
\hline${ }^{1} \mathrm{~L}^{*}=$ lightness; $\mathrm{a}^{*}=$ redness; $\mathrm{b}^{*}=$ yellowness; $\mathrm{pHu}=$ ultimate $\mathrm{pH}$ of the \\
breast. \\
${ }^{2} \mathrm{NS}=P>0.05 ; *=P<0.05$.
\end{tabular}


could be achieved by decreasing manure $\mathrm{pH}$ or $\mathrm{WC}$, which might limit the volatilization of $\mathrm{N}$ during rearing and storage (Lefcourt and Meisinger, 2001). As the greater WC of excreta of D+ birds should enhance $\mathrm{N}$ volatilization, $\mathrm{N}$ losses should be directly recorded to draw definitive conclusions.

The selection experiment based on AMEn modified nutrient retention rates and could thus impact body composition and perhaps also meat and bone quality. In the present study, BMY was less in $\mathrm{D}+$ than in $\mathrm{D}-$ and RL at $7 \mathrm{~d}$. This is consistent with more intense development of the GIT during the first days of life in $\mathrm{D}+$ than in $\mathrm{D}$ - and RL birds, which implies that $\mathrm{D}+$ birds have proportionally less energy to invest in muscle development. Differences in BMY were not significant at $3 \mathrm{wk}$ of age, which is consistent with phenotypic results at $23 \mathrm{~d}$ of age and with the low genetic correlation estimated between AMEn and $\operatorname{BMY}\left(r_{\mathrm{g}}=0.05 ; \mathrm{H}\right.$. de Verdal, unpublished data). The greater BMY and reduced AFY for D+ and RL birds compared with D- birds at $53 \mathrm{~d}$ could be explained by the differences in feed consumption and the metabolic consequences. Indeed, an increase in insulin secretion by the pancreas in response to greater feed consumption is known to increase fat deposition and, conversely, to decrease muscle protein deposition (Tomas et al., 1998; Buyse et al., 1999). Future studies should also examine the secretion concentrations of gastrointestinal hormones, which could explain the differences in body composition between D- and RL birds. Furthermore, Tomas et al. (1998) showed that the improvement in the efficiency of feed use is negatively linked to proteolysis activity and increases BMY and reduces AFY (Huyghebaert and Pack, 1996). Because $\mathrm{D}+$ and RL birds retained more $\mathrm{N}$ than $\mathrm{D}-$ birds, the $\mathrm{D}+$ line should show reduced proteolysis and increased breast meat mass. Thus, selection on high AMEn values improved BMY and AFY through a reduction in NE/WG as compared with D- birds and did not affect these traits compared with RL birds.

In the present study, RL birds showed $1.06 \%$ higher $\mathrm{pHu}$ than $\mathrm{D}+$ birds, but the meat color traits $\left(\mathrm{L}^{*}, \mathrm{a}^{*}\right.$, and $\left.b^{*}\right)$ were not significantly different between the 3 lines. The differences in $\mathrm{pHu}$ between lines seemed too small to cause noticeable changes in meat quality, and selection for AMEn should therefore not affect breast meat quality. However, according to Le BihanDuval et al. (2001) and Duclos et al. (2007), the breast meat of these 3 lines was rather acidic $(\mathrm{pHu}<5.7)$, which could result in impairment of the technological processing ability.

Bone strength is important from an economic and welfare point of view. Although RL birds showed $17.0 \%$ to $36.4 \%$ greater $\mathrm{BBS}$ than $\mathrm{D}+$ and $\mathrm{D}$ - at 7 and 21 d, chickens of the 3 lines did not show any differences in BBS at slaughter age. This was consistent with the very high genetic correlation between $\mathrm{BBS}$ and $\mathrm{BW}$ at $23 \mathrm{~d}(0.93 ; \mathrm{H}$. de Verdal, unpublished data) and with the fact that RL birds were heavier than D+ and D- at 7 and $21 \mathrm{~d}$ but not at $53 \mathrm{~d}$. These results thus suggest that selection did not modify bone strength, a major risk of fracture at slaughter age.

\section{Conclusion}

This study clearly showed that selecting chickens for high AMEn values could improve DM use and retention of $\mathrm{N}$ and $\mathrm{P}$, thus reducing the environmental impact of chicken excretion over the whole rearing period. Furthermore, such selection would not affect body composition and meat and bone quality traits at slaughter age compared with the reference genotype. This could be at least partly explained by the differential development of the GIT between the lines. Comparison of the hormone profiles of the 3 lines might help us to understand the mechanisms underlying the changes in terms of excretion, GIT morphology, and body composition observed in the present study.

\section{LITERATURE CITED}

Bastianelli, D., L. Bonnal, H. Juin, S. Mignon-Grasteau, F. Davrieux, and B. Carré. 2010. Prediction of the chemical composition of poultry excreta by near infrared spectroscopy. J. Near Infrared Spectrosc. 18:69-77.

Bolan, N. S., A. A. Szogi, T. Chuasavathi, B. Seshadri, M. J. Rothrock Jr., and P. Panneerselvam. 2010. Uses and management of poultry litter. World's Poult. Sci. J. 66:673-698.

Bourdillon, A., B. Carré, L. Conan, J. Duperray, G. Huyghebaert, B. Leclercq, M. Lessire, J. McNab, and J. Wiseman. 1990. European reference method for the in vivo determination of metabolizable energy with adult cockerels - Reproducibility, effect of food-intake and comparison with individual laboratory methods. Br. Poult. Sci. 31:557-565.

Buyse, J., F. R. Leenstra, M. Zeman, G. Rahimi, and E. Decuypere, 1999. A comparative study of different selection strategies to breed leaner meat-type poultry. Poult. Avian Biol. Rev. 10:121-142.

de Verdal, H., S. Mignon-Grasteau, C. Jeulin, E. Le Bihan-Duval, M. Leconte, S. Mallet, C. Martin, A. Narcy. 2010. Digestive tract measurements and histological adaptation in broiler lines divergently selected for digestive efficiency. Poult. Sci. 89:1955-1961.

de Verdal, H., A. Narcy, D. Bastianelli, H. Chapuis, N. Même, S. Urvoix, E. Le Bihan-Duval, and S. Mignon-Grasteau. 2011a. Improving the efficiency of feed utilization in poultry by selection. 1 . Genetic parameters of anatomy of the gastro-intestinal tract and digestive efficiency. BMC Genet. 12:1-9.

de Verdal, H., A. Narcy, H. Chapuis, D. Bastianelli, N. Même, S. Urvoix, E. Le Bihan-Duval, and S. Mignon-Grasteau. 2011b. Improving the efficiency of feed utilization in poultry by selection. 2 . Genetic parameters of excretion traits and correlations with anatomy of the gastro-intestinal tract and digestive efficiency. BMC Genet. 12:1-10.

Duclos, M., C. Berri, and E. Le Bihan-Duval. 2007. Muscle growth and meat quality. J. Appl. Poult. Res. 16:107-112. 
Garcia, V., J. Gomez, S. Mignon-Grasteau, N. Sellier, and B. Carre. 2007. Effects of xylanase and antibiotic supplementations on the nutritional utilisation of a wheat diet in growing chicks from genetic $\mathrm{D}+$ and $\mathrm{D}$ - lines selected for divergent digestion efficiency. Animal 1:1435-1442.

Gilbertson, C. B., F. A. Norstadt, A. C. Mathers, R. F. Holt, A. P. Barnett, T. M. McCalla, C. A. Onstad, and R. A. Young. 1979. Animal waste utilization on cropland and pastureland: A manual for evaluating agronomic and environmental effects. U.S. Gov. Print. Off., Washington, DC.

Huyghebaert, G., and M. Pack. 1996. Effects of dietary protein content, addition of nonessential amino acids and dietary methionine to cysteine balance on responses to dietary sulphur-containing aminoacids in broilers. Br. Poult. Sci. 37:623-639.

Institut Technique de l'Aviculture. 2001. Les déjections avicoles. Sci. Tech. Avicoles Hors Ser., 27-33.

Laird, A. K., S. A. Tyler, and A. D. Barton. 1965. Dynamics of normal growth. Growth 29:233-248.

Le Bihan-Duval, E., C. Berri, E. Baeza, N. Millet, and C. Beaumont. 2001. Estimation of the genetic parameters of meat characteristics and of their genetic correlations with growth and body composition in an experimental broiler line. Poult. Sci. 80:839-843.

Lefcourt, A. M., and J. J. Meisinger. 2001. Effect of adding alum or zeolite to dairy slurry on ammonia volatilization and chemical composition. J. Dairy Sci. 84:1814-1821.

Mahimairaja, S., N. S. Bolan, M. J. Hedley, and A. N. MacGregor. 1990. Evaluation of methods of measurement of nitrogen in poultry and animal manures. Nutr. Cycl. Agroecosyst. 24:141-148.

Mignon-Grasteau, S., M. Bourblanc, B. Carré, J. Y. Dourmad, H. Gilbert, H. Juin, J. Noblet, and F. Phocas. 2010a. La réduction des rejets avicoles et porcins par la sélection. INRA Prod. Anim. 23:415-426.

Mignon-Grasteau, S., O. Lafeuille, J. Y. Dourmad, S. Hillion, D. Bastianelli, C. Arnould, F. Phocas, and B. Carré. 2010 b. Consequences of selection for digestibility on feeding activity and excretion. World's Poult. Sci. J. 66:615-620.

Mignon-Grasteau, S., N. Muley, D. Bastianelli, J. Gomez, A. Peron, N. Sellier, N. Millet, J. Besnard, J. M. Hallouis, and B. Carré. 2004. Heritability of digestibilities and divergent selection for digestion ability in growing chicks fed a wheat diet. Poult. Sci. 83:860-867.
Miles, D. M., D. E. Rowe, and T. C. Cathcart. 2011. Litter ammonia generation: Moisture content and organic versus inorganic bedding materials. Poult. Sci. 90:1162-1169.

Moore, P. A., Jr., T. C. Daniel, C. W. Wood, and A. N. Sharpley. 1995. Poultry manure management: Environmentally sound options. J. Soil Water Conserv. 50:321-327.

Nahm, K. H. 2007. Feed formulations to reduce N excretion and ammonia emission from poultry manure. Bioresour. Technol. 98:2282-2300.

Palo, P. E., J. L. Sell, F. J. Piquer, M. F. Soto-Salanova, and L. Vilaseca. 1995. Effect of early nutrient restriction on broiler chickens. 1. Performance and development of the gastrointestinal tract. Poult. Sci. 74:88-101.

Pym, R. A. E. 1990. Nutritional genetics. In: R. D. Crawford, editor, Poultry Breeding and Genetics: Developments in Animal and Veterinary Sciences. Elsevier, Amsterdam. p. 847-876.

Rougière, N., J. Gomez, S. Mignon-Grasteau, and B. Carré. 2009. Effects of diet particle size on digestive parameters in $\mathrm{D}+$ and $\mathrm{D}$ - genetic chicken lines selected for divergent digestion efficiency. Poult. Sci. 88:1206-1215.

Sauvant, D., J. M. Pérez, and G. Tran, editors. 2004. Tables of composition and nutritional value of feed materials: Pigs, poultry, cattle, sheep, goats, rabbits, horses, fish. Inst. Natl. Rech. Agron., Assoc. Fr. Zootech., Paris.

Sharpley, A. N. 1999. Agricultural phosphorus, water quality, and poultry production: Are they compatible? Poult. Sci. 78:660-673.

Svihus, B. 2011. The gizzard: Function, influence of diet structure and effects on nutrient availability. World's Poult. Sci. J. 67:207-223.

Taylor, R. D., and G. P. D. Jones. 2004. The incorporation of whole grain into pelleted broiler chicken diets. II. Gastrointestinal and digesta characteristics. Br. Poult. Sci. 45:237-246.

Tomas, F. M., R. A. E. Pym, J. P. McMurtry, and G. L. Francis. 1998. Insulin-like growth factor (IGF)-I but not IGF-II promotes lean growth and feed efficiency in broiler chickens. Gen. Comp. Endocrinol. 110:262-275.

White, W. C., and D. N. Collins. 1982. The fertilizer handbook. Fertilizer Inst., Washington, DC.

Wu, Y. B., and V. Ravindran. 2004. Influence of whole wheat inclusion and xylanase supplementation on the performance, digestive tract measurements and carcass characteristics of broiler chickens. Anim. Feed Sci. Technol. 116:129-139. 
References

This article cites 27 articles, 8 of which you can access for free at: http://www.journalofanimalscience.org/content/91/2/613\#BIBL 